\title{
Battle lines form over fetal tissue research
}

\section{- New reseach coalition mounts lobby offensive Two-thirds of Congress is distant goal}

\section{Washington}

THIRTY-SEVEN research and health groups, joined under a banner of "research freedom", are planning to mount the strongest attack yet on a four-year-old US moratorium on federally funded research on fetal tissue for human transplantation.

Spurred by support in the House of Representatives, where a bill that would overturn the moratorium passed by a large margin last summer, the members of the new Coalition for Research Freedom are rallying behind similar legislation in the Senate. Known as the Research Freedom Act of 1991, and introduced by Senator Brock Adams (Democrat, Washington), the Senate bill is due to be incorporated into legislation reauthorizing the National Institutes of Health (NIH). The Senate Labor and Human Resources Committee is expected to vote on it early next month.

It is on the Senate floor, however, that the research advocates will face their most difficult hurdle. The support of a majority of the lawmakers will probably not be enough to enact the legislation; a twothirds advantage is needed to override a threatened presidential veto. Last July, the House bill - introduced by Representative Henry Waxman (Democrat, California) - passed 274-144: a clear majority, but not two-thirds. To get the required votes in the Senate, supporters of the Adams bill will have to break partisan lines and convince traditionally anti-abortion legislators that the fetal tissue research question is not simply the abortion question in a scientific disguise.

One example of the kind of convert that the research groups need is Mark Hatfield, an anti-abortion Republican senator from Oregon. In a letter dated 26 November to the American Federation for Clinical Research, one of the members of the Washington-based coalition, Hatfield explained why he had decided to break with the anti-abortion lobby and back the fetal-tissue measure: "Given the great promise of fetal tissue transplants ... I believe the truly 'pro-life' position on this issue is that of supporting the research."

Coalition member are now conducting a 'straw poll' to test the political winds in Congress. But there is a difference between philosophical support for a worthy cause, and actually being the swing vote responsible for President George Bush's first veto defeat. So far, the coalition's attempts to separate fetal-tissue research from the abortion debate have been partially successful; supporters of the
Waxman bill included some 70 'pro-life' congressmen. Although they are encouraged by their success, coalition members harbour no illusions about the difficulty in getting votes to sustain a veto.

"It's been a slow process of education," says Joan Samuelson, a California lawyer with Parkinson's disease who has been one of the strongest supporters of

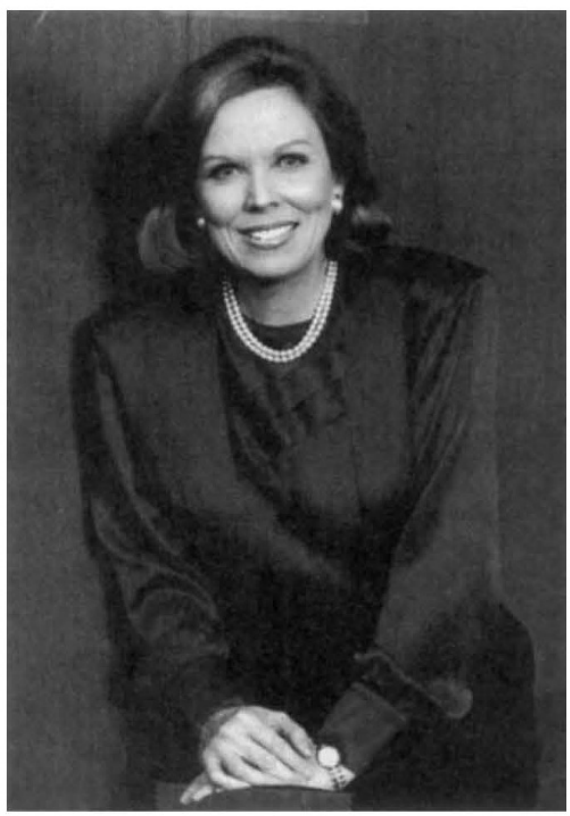

Bernadine Healy supports fetal research, but as $\mathrm{NIH}$ director must support the moritorium.

legislation overturning the moratorium on fetal tissue transplants, which are being explored as a possible cure for Parkinson's. Rather than focusing on the ethics of fetal tissue research, the coalition is emphasizing its scientific benefits and the safeguards in the legislation that they say would deter women from having abortions in order to donate fetal tissue to science. Opponents of fetal tissue transplantation argue, against available evidence, that the research would increase the rate of elective abortions.

Beginning with the report of a 1988 advisory committee to the National Institutes of Health (NIH), proponents of fetal tissue research have devised elaborate procedures to ensure that a woman would not know to whom tissue from her fetus would go, nor receive any payment for the tissue. Such 'walls' between the research and the abortion decision are in the current legislation, as well. But anti-abortion activist argue that it is not enough not to know the name of the potential recipient; just knowing that some good may come of an abortion could be enough to persuade an undecided woman, they say.

Because fetal tissue grows rapidly and is less likely that tissue from adults to be rejected by the body's immune system, it has been a focus of transplant research since the $1950 \mathrm{~s}$. But with the exception of its use in DiGeorge's syndrome, a rare digestive disorder, its effectiveness is still not clear. Research in Mexico, Sweden and the United States has shown some promising results in the treatment of Parkinson's disease, but the procedure is still experimental.

The US moratorium on fetal tissue research applies only to federally funded work on transplanting tissue from human fetuses. NIH director Bernadine Healy, who served on the NIH fetal tissue advisory panel before joining the agency, has testified that the agency is spending about $\$ 8$ million a year on fetal tissue research that is not covered by the moratorium, mostly for nontransplant research and animal tissue. A small amount of independent research is also funded by private sources, although, as Samuelson says, "the moratorium has placed a stigma on the work, making it look inappropriate" and discouraging further private support. Coalition members argue that permitting federally funded - and regulated - fetal tissue research will ensure that private efforts comply with the safeguards outlined in the congressional legislation.

Other research subjects that have fallen afoul of politics have a similar abortion link. In-vitro fertilization research is the subject of another Administration moratorium, on the grounds that several ova are usually fertilized in the process, although they are not all implanted in the womb. These discarded cells are tantamount to abortions, pro-life activists claim. And although RU-486, the abortion drug, may have medical application for breast cancer and Cushing's syndrome, Roussel-Uclaf, the French pharmaceutical company that produces it, has restricted its use in the US because of anti-abortion fervor.

Although the drive for support from two-thirds of the Congress is the current focus for lobbying, a lawsuit remains a possibility. Because the moratorium was introduced without the normal notice and comment period required for federal regulations, it may be in violation of the Administrative Procedures Act, which dictates how regulations must be made. Several groups, led by the Chicago-based United Parkinson Foundation, have threatened to sue the government. But before embarking on what promises to be a long and protracted legal battle, the coalition will concentrate on Congress in its effort to see the fetal tissue transplantation moratorium come to an end.

Christopher Anderson 